\title{
Identification of Two Types of Stem Cells in Methylene Blue-stained Sections of Untreated and Diethylstilbestrol-treated Human Prostate Cancer and Their Characterization by Immunogold Localization of CD133
}

\author{
AKHOURI A. SINHA ${ }^{1,2,3}$ and MICHAEL J. WILSON ${ }^{1,3,4}$ \\ ${ }^{1}$ Research Service, Minneapolis Veterans Affairs Healthcare System, Minneapolis, MN, U.S.A.; \\ ${ }^{2}$ Department of Genetics, Cell Biology and Development, ${ }^{3}$ Masonic Cancer Center, and \\ ${ }^{4}$ Laboratory of Medicine and Pathology, University of Minnesota, Minneapolis, MN, U.S.A.
}

\begin{abstract}
Background: The basal compartment of the prostatic acinus harbors stem and basal cells, whereas the luminal compartment contains cuboidal and columnar cells. Mutation in the genes of stem cells is required for benign (normal) prostate to develop into prostatic adenocarcinoma. Stem/basal cells survive androgen deprivation therapy in humans and castrated mice to repopulate glandular cells by proliferation when stimulated by androgen. We hypothesized that using different embedding and staining methods, it would be possible to identify two types of stem cells in human prostate by localization of CD133. Materials and Methods: Prostate biopsy or prostatectomy pieces from 13 untreated and eight diethylstilbestrol-treated men with prostate cancer were sectioned, stained by methylene blue and CD133 was localized by immunogold technique. Results: Methylene blue stained basic proteins in dark basal cells, but not in light cells. Light basal cells expressed androgen receptors and dark cells estrogen receptors. Light and dark cells expressed CD133, indicating them to be stem cells. Light stem cells produced the lineage of columnar/cuboidal cells. Estrogen-dependent dark cells produced a lineage of columnar/cuboidal cells, that also
\end{abstract}

*Part of this study was presented at the annual meeting of the Society for the Study of Reproduction at Milwaukee, Wisconsin on August 2, 2010. Presentation No: 696. Abstract was published in Biology of Reproduction.

Correspondence to: Akhouri A. Sinha, Ph.D., VAMC Research Service (151), Building 70, One Veterans Drive, Minneapolis, MN, 55417, U.S.A. Tel. +1 6124672846, Fax: +1 6127252093, e-mail: sinha001@umn.edu, Akhouri.Sinha@Va.Gov

Key Words: Stem cells, mutation, proliferation, stem cell lineage, columnar/cuboidal cells, androgen-dependent, estrogen-dependent, glandular cells, methylene blue, CD133 localization, immunogold techniques. expressed estrogen receptors. Conclusion: Our analysis indicates that stem/basal cells are privileged cells in the basal compartment. Stem cells are not under the regulation of steroid hormones, whereas their lineage of cuboidal/columnar cells are. The lineage of androgen-dependent cells are columnar/cuboidal cells and the lineage of estrogen-dependent cells are also columnar/cuboidal cells. Epon-embedding and methylene blue staining showed two types of CD133-positive stem cells in prostate. Paraffin sections did not show two types of stem cells in prostate and bone marrow leukemia cells. Our study indicates the continuity of embryonic stem cells into adult prostate as organ-specific stem cells. To our knowledge, this is the first study to identify two types of stem cells in human prostate.

Stem cells are critical in embryos for the development of an organ (such as prostate, breast) and they are essential for replenishing adult prostatic glandular cells and malignant tissues (1-3). Basal and luminal compartments were identified in normal (benign) prostate and prostate cancer (PC) $(4,5)$. We determined that the basal compartment harbors basal/stem cells, and possibly niche cells, and the luminal compartment contains columnar/cuboidal cells and neuroendocrine cells $(4,5)$. Stem cells reside in the basal cell compartment (3-5). About $1 \%$ of human basal cells in human prostatic epithelium express the stem cell marker CD133 (4, 5). Many studies have identified and characterized PC stem cells using a variety of markers (such as CD44, CD133, $\alpha 2$ B-1-integrin and E-cadherin $(4,6,7)$. CD133 is the most common marker used for identifying stem cells $(5,8)$. These studies identified a single type of PC stem cell on frozen cryostat and paraffin-embedded prostate tissue sections by immunohistochemical or immunofluorescence techniques using the above markers $(2,5,6,9)$. Stem cells are a subset of basal cells and function as a reservoir of self-sustaining stem cell type $(3,10,11)$. Basal cells are less differentiated 
than stem cells (unpublished observation). Prostatic stem cells proliferate to replenish the columnar/cuboidal cells when they are lost due to sloughing, or cell death in the acinar lumen $(2,4,9,10)$.

Stem cells differentiate to produce luminal compartment columnar/cuboidal cells which are prostatic secretory cells (2, $5,11,12)$. Stem cells in adult prostate proliferate and repopulate partially differentiated or fully differentiated columnar/cuboidal cells in benign (normal) and malignant prostate (13). The basal compartment also contains niche cells (12). Basal/stem cells are usually associated with the niche cells, but their exact function or origin are unknown. They might function like Sertoli cells found in testis. The luminal compartment contains differentiated cuboidal/ columnar and neuroendocrine cells, whereas the stroma contains muscle cells and fibroblasts $(2,4,9)$. Differentiated cells of benign prostate lack an unlimited potential for proliferation, whereas gene mutation in stem cells can impart the potential for unlimited proliferation in cancerous cells. Our analysis of the above literature indicates that the basal compartment provides a privileged area for stem/basal cells in the prostate.

Specific agents which can induce mutation of prostatic stem cells are unknown, but mutation may be due to specific molecules in prostatic secretion, environmental toxins/ chemicals, viruses (such as TRIM5 alpha), all supplied to the prostate by the capillaries around the acinus (Figure 1).

Several steroid hormones (androgen, estrogen and progesterone) and their receptors regulate functions of prostatic cells in the luminal compartment and in PC (14-17). The amount and ratios of these hormones and their receptors differ in steroid-dependent normal prostate and breast and their cancers, and other steroid-dependent organs (such as uterus, cervix). Prostate and PC have a preponderance of androgens and androgen receptors, much as breast tissue and its cancer have a preponderance of estrogens and estrogen receptors. Estrogen has been found in prostate $(14,18)$ and other tissues (15-17), but its role in prostate and PC has not been accepted by the supporters of the androgen dependence of prostate $(19,20)$. Methylation of estrogen receptor in PC was found to be correlated to tumor progression (21). Androgen deprivation therapy (ADT) and diethylstilbestrol (DES) treatment lead to degeneration and sloughing of cuboidal/columnar cells, but not of stem and basal cells in human prostate $(2,9,22)$. Likewise, castration of mice and rats leads to degeneration and sloughing of glandular cells, but not of stem/basal cells $(23,24)$. When stem cells are stimulated by androgen, they repopulate the glandular cuboidal/columnar cells (24). Our previous study indicated that when androgen is removed/reduced by ADT, the role of estrogen emerges because the inhibitory effect of androgen is greatly diminished (23). We hypothesized that by using different embedding and staining methods followed by localization of CD133 as a stem cell marker using immunogold techniques, it might be shown whether there is more than one type of stem cell in prostate and PC.

\section{Materials and Methods}

Areas suspected of PC were biopsied or removed by radical prostatectomy from untreated and DES-treated patients. Prostate specimens were submitted to the Pathology Service at the Minneapolis Veterans Affairs Medical Center (VAMC). After diagnosis of cancer, the pathologist provided tissue pieces for this study. Patients in our study had not received any hormone treatment, or chemotherapy, prior to biopsy or surgery. Biopsy or prostatectomy specimens were collected between 1972 and 1975 at the VAMC. We received 13 samples from untreated patients, eight from patients treated with DES alone or DES plus Provera and four from benign prostatic hyperplasia cases. All samples were collected according to the VAMC and the University of Minnesota Review Board guidelines. The authors appointment required dual approval. No University of Minnesota specimens were used in this study.

Clinical details of all DES-treated patients were published elsewhere (22). The DES treatment of cases ranged from 37 days to 18 years and 9 days $(22,23)$. The age of DES-treated patients ranged from 53 to 86 years, with a mean \pm standard error of $69.37 \pm 2.83$ years. The age of untreated patients ranged from 58 to 79 years, with a mean \pm standard error of $70.54 \pm 3.60$ years.

Briefly, prostate pieces were fixed in a combination of paraformaldehyde and glutaraldehyde $(18,22,23)$. After washing, pieces were post-fixed in $1 \%$ to $2 \%$ buffered osmium-tetroxide, washed and dehydrated in graded ethanol, and then embedded in Epon 812 as previously described (22). Sections were graded by Drs. Donald F. Gleason and Nancy A. Staley, former staff pathologists of the Minneapolis VAMC. Patients had PC with pathological grade III and IV tumors, which are comparable to Gleason histological scores 6 to 10 (25). Clinical stages were B-D (26).

Monoclonal antibody against CD133 was kindly provided by Drs. John Ohlfest and. S. K. Swaminathan (University of Minnesota, Minneapolis, MN, USA). This antibody was characterized by them and was found suitable for localization of CD133 in neuroblastoma (27) and human prostate (22). We used CD133 antibody on formalinfixed, paraffin-embedded sections of 84 prostate cases and a few leukemia bone marrow samples (as positive control) using an immunohistochemical method reported before (22). This CD133 antibody was also used in localization studies on Epon-embedded sections (1-to 2- $\mu$ m-thick) which were prepared using a LKB III Ultratome (LKB produkter AB, Bromma, Sweden) or Reichert-Jung ultracut microtome (C. Reichert AG, Wien Austria. Sections were stained with methylene blue for morphological analysis $(22,23)$, methylene blue stains basic proteins (28). Methylene blue staining was carried out prior to localization of CD133.

For immunogold localization of CD133, methylene blue-stained sections were etched for 10 min with $10 \% \mathrm{H}_{2} \mathrm{O}_{2}$, washed with distilled water for $10 \mathrm{~min}$ (four changes), subjected to antigen retrieval for 10 minutes with citrate buffer $(\mathrm{pH}$ 6.0; Invitrogen Corp., Fredrick, MD, USA), and washed with phosphate-buffered saline. After blocking of non-specific reaction product using a mixture of $1-2 \%$ bovine serum albumin and $1-2 \%$ normal goat or sheep serum, localization of CD133 IgG was achieved using rabbit or mouse secondary antibody IgGs or protein A conjugated with 15 to $25 \mathrm{~nm}$ Aurion gold particles (Aurion Immuno Gold Reagents, Wageningen, the Netherlands). The reaction products were enhanced 


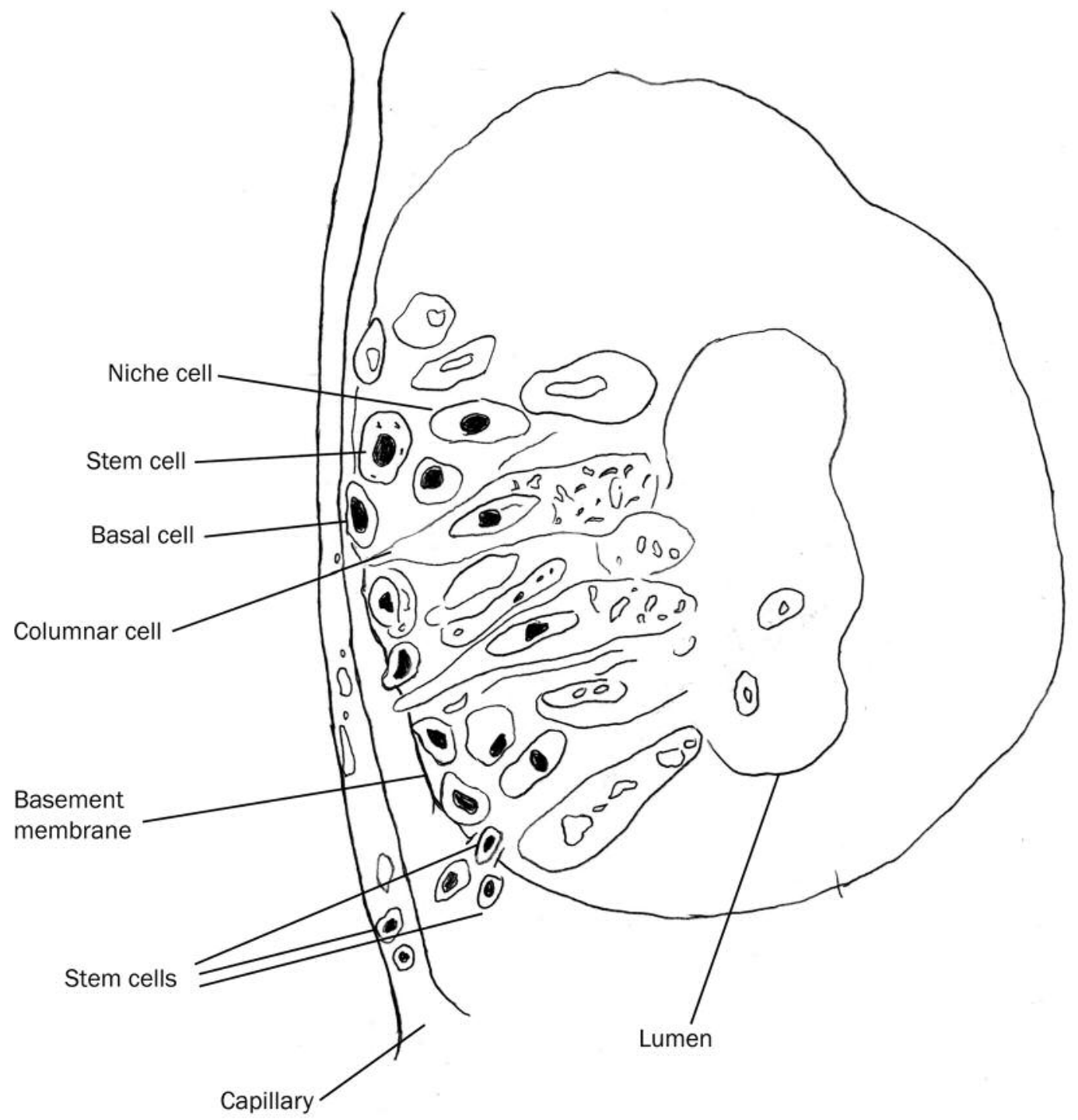

Figure 1. Diagram of a prostatic acinus. The figure illustrates a prostatic acinus and a closely associated capillary in the stroma. Lymphatic vessels are not illustrated. Basal cells are spindle-shaped cells that are closely associated with the basement membrane. They have few cytoplasmic organelles and the nucleus occupies most of the cell. Stem cells are found slightly away from the basal cells and are more rounded or oval and have more cytoplasmic organelles than basal cells. Niche cells do not reach the basement membrane nor the acinar lumen. These have more cytoplasmic organelles than both basal and stem cells. Breaks in the basement membrane allows passage of stem cells to the prostatic stroma and capillary. Stem cells may enter lymphatic vessels. The lumen contains secretory material and sloughed apical portions of columnar cells. Columnar cells reach the basement membrane and the lumen.

using an Aurion R-Gent silver enhancement kit (Electron Microscopy Sciences, Hatfield, PA, USA). Methylene blue staining and CD133 localization by immunogold and silver enhancement did not differ in light and dark cells (23). Dark cells stained with methylene blue and light cells did not. For negative control, normal serum of the animal used in preparation of antibody was used or CD133 antibody was omitted. Negative control sections did not show CD133 immunostaining. For positive control, leukemia bone marrow sections showing expression of CD133 were used. Images of methylene blue and immunogold-stained sections were acquired directly from slides on a Zeiss microscope equipped with a Nikon digital camera to a computer. Brightness of entire images was adjusted using Photoshop, which did not effect individual light and dark cells.

Sections were then assessed visually for the presence of light and dark cells, their location and CD133 localization.

\section{Results}

Previously, paraffin sections of 84 PC cases with Gleason histological scores of 5 to 9 showed there to be a single type 

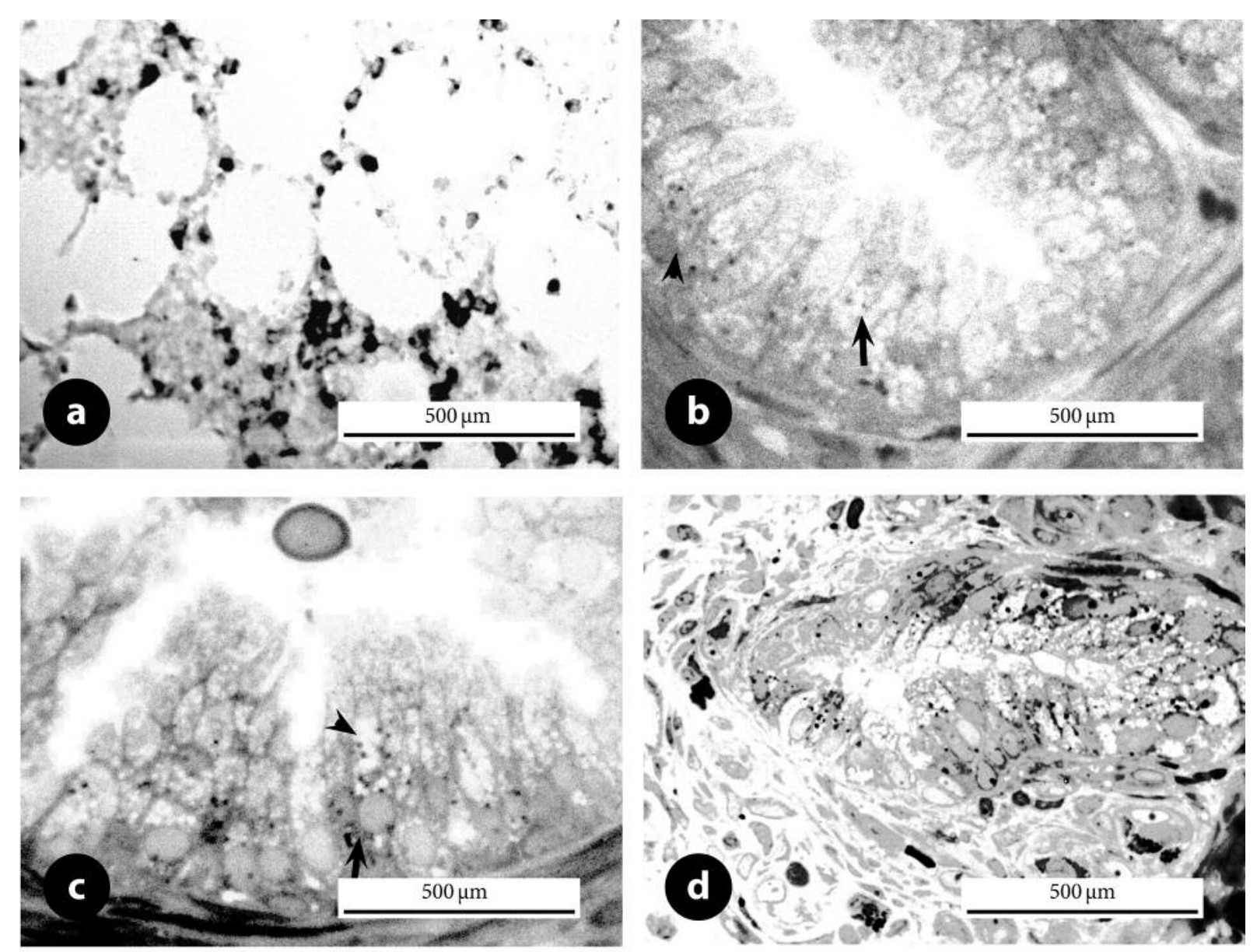

Figure 2. Stem cells in untreated prostate. a: Paraffin section of leukemia bone marrow showing localization of CD133 in nuclei by immunohistochemical methods. Paraffin sections showed a single type of stem cell. b: Epon-embedded and methylene blue-stained section of patients with untreated benign prostate showing localization of CD133 in stem cells by immunogold particles. The arrowhead indicates a dark stem cell. Columnar cells localized CD133 by gold particles (arrow), suggesting that some features of stem cells are also present in columnar/cuboidal cells. The absence of gold particles in glandular lumen indicates that immunogold particles do not localize in lumen, but localize where antigen is present in the cell. c: Methylene bluestained section from the case shown in (b) illustrates untreated high-grade prostatic intraepithelial neoplasia. The arrowhead indicates a glandular cell. Dark and light stem cells exhibit localization of CD133 by immunogold particles (arrow). Gold particles are not present in the glandular lumen, indicating that antigen is not present in the lumen. This demonstrates the specificity of antigen-antibody reaction. d: Methylene blue-stained section of untreated prostate cancer with dark and light stem cells and some columnar cells exhibiting localization of CD133 by immunogold particles.

of stem cell after localization of CD133 (unpublished data). The Gleason grading system is now universally accepted for grading of prostate cancer. This result is consistent with many other studies $(2-6,9,12)$. We used paraffin sections of leukemia bone marrow as controls for localization of CD133 (Figure 2a). They also showed there to be a single type of stem cell. In contrast, Epon-embedded sections stained with methylene blue showed dark and light stem cells and each type of stem cell localized CD133 immunogold particles, which were also localized in some columnar/cuboidal cells of benign prostate (Figure $2 b$ ). This indicates that paraffin embedding is inadequate to show that two types of stem cells exist. Gold particles were specific for the cell constituents and particles were not present in the lumen of this gland. In high-grade prostatic intraepithelial neoplasia, CD133 was localized in dark and light stem cells, as well as in clustered cuboidal cells (Figure 2c). Gold particles were localized at different heights of the prostatic intraepithelial neoplasia cells. Lumen in high-grade prostatic intraepithelial neoplasia did not contain gold particles, indicating that localization was specific. In untreated malignant prostate, columnar/ cuboidal cells were greatly reduced in cell height and dark and light stem cells localized CD133 as shown by immunogold particles (Figure 2d). In a favorably cut section, 

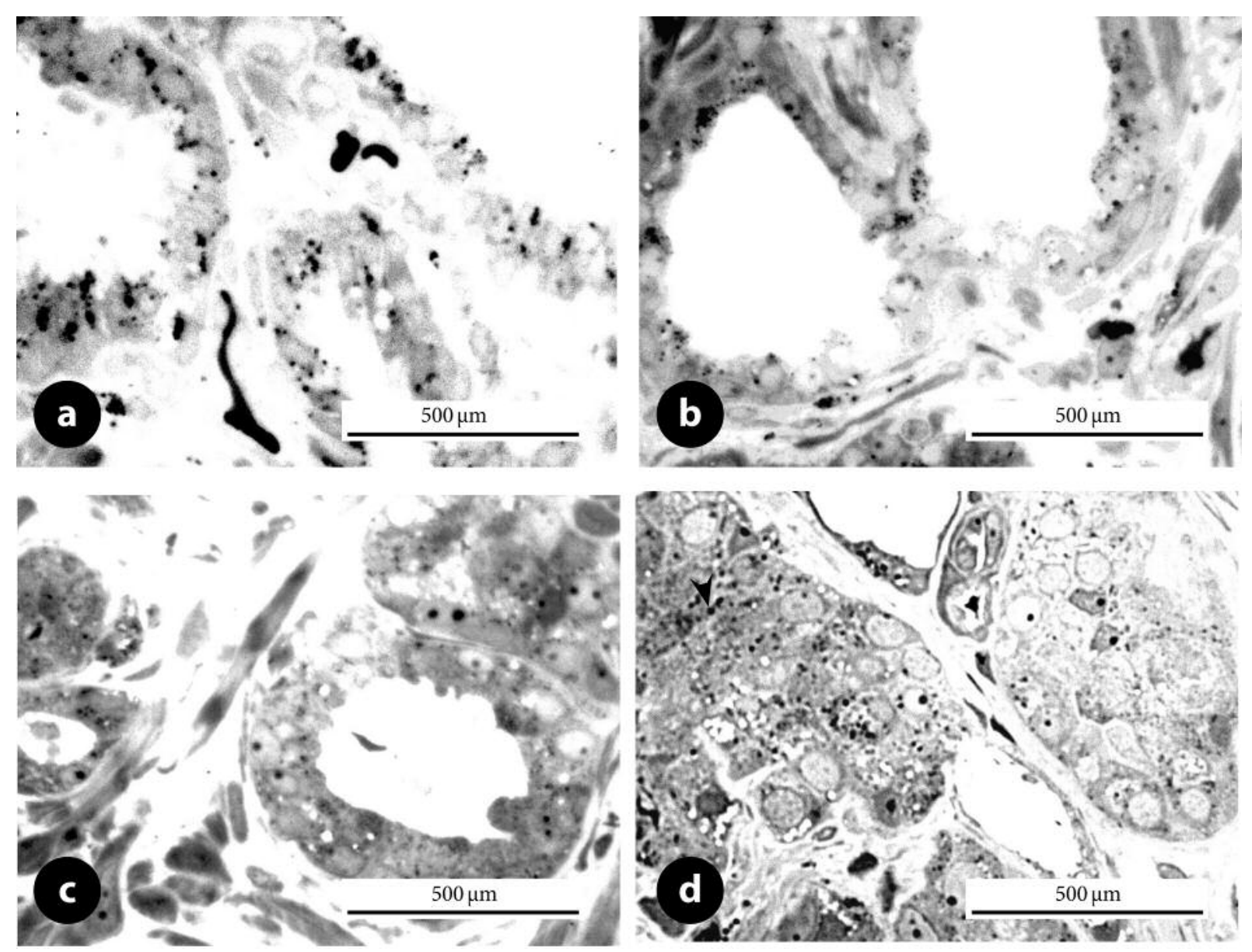

Figure 3. Stem cells in untreated prostate cancer. a: Untreated prostate cancer shows localization of CD133 in dark and light stem cells by immunogold particles. Glandular (columnar) cells also have localization of gold particles. No gold particles are present in the acinar lumen, indicating that the lumen does not have antigen. $b, c$ : Untreated prostate cancer showing different areas with localization of CD133 in dark and light stem cells by immunogold particles. d: Untreated prostate cancer showing localization of CD133 in dark and light stem cells by immunogold particles. Some stem cells invading stroma have immunogold particles.

clusters of light and dark basal stem cells expressed CD133 as shown by localization of immunogold particles (Figure $2 d)$. The section shown in Figure $2 d$ also exhibited invasive dark stem cells with gold particles.

In a set of untreated PC, stem cells were localized by CD133-labeled gold particles. Columnar and cuboidal cells were at variable heights within acini. Some of these cells contained gold particles, indicating that they may function as stem cells. Immunogold particles did not localize in stromal cells or acinar lumen, indicating that antigens were not present in the lumen of the gland (Figure 3a). In another area of the same section, light and dark stem cells also illustrated CD133 localization by immunogold particles (Figure 3b). In untreated PC, CD133 was localized in light and dark stem cells and occasional invasive cells in the stroma (Figure 3c). Some areas had greater numbers of stem cells than others. Immunogold particles localized in nuclei of light and dark basal/stem cells (Figure 3b and c). In some sections, invasive stem cells were found in the stroma as shown by localization of gold particles (Figure 3d).

In the prostate of a patient treated with DES for 67 days, CD133 was localized by immunogold particles in epithelial as well as in dark and light basal stem cells (Figure 4a). Glandular epithelium was greatly reduced in cell height (Figure 4a). In PC treated with DES for 67 days, gold particles were localized in most basal/stem cells (Figure 4b). In the prostate from a patient treated for 37 days with DES, there were many invasive cells with CD133 localized by gold particles (Figure 4c). A sample of PC treated for 37 days with DES illustrated localization of CD133 in dark and 

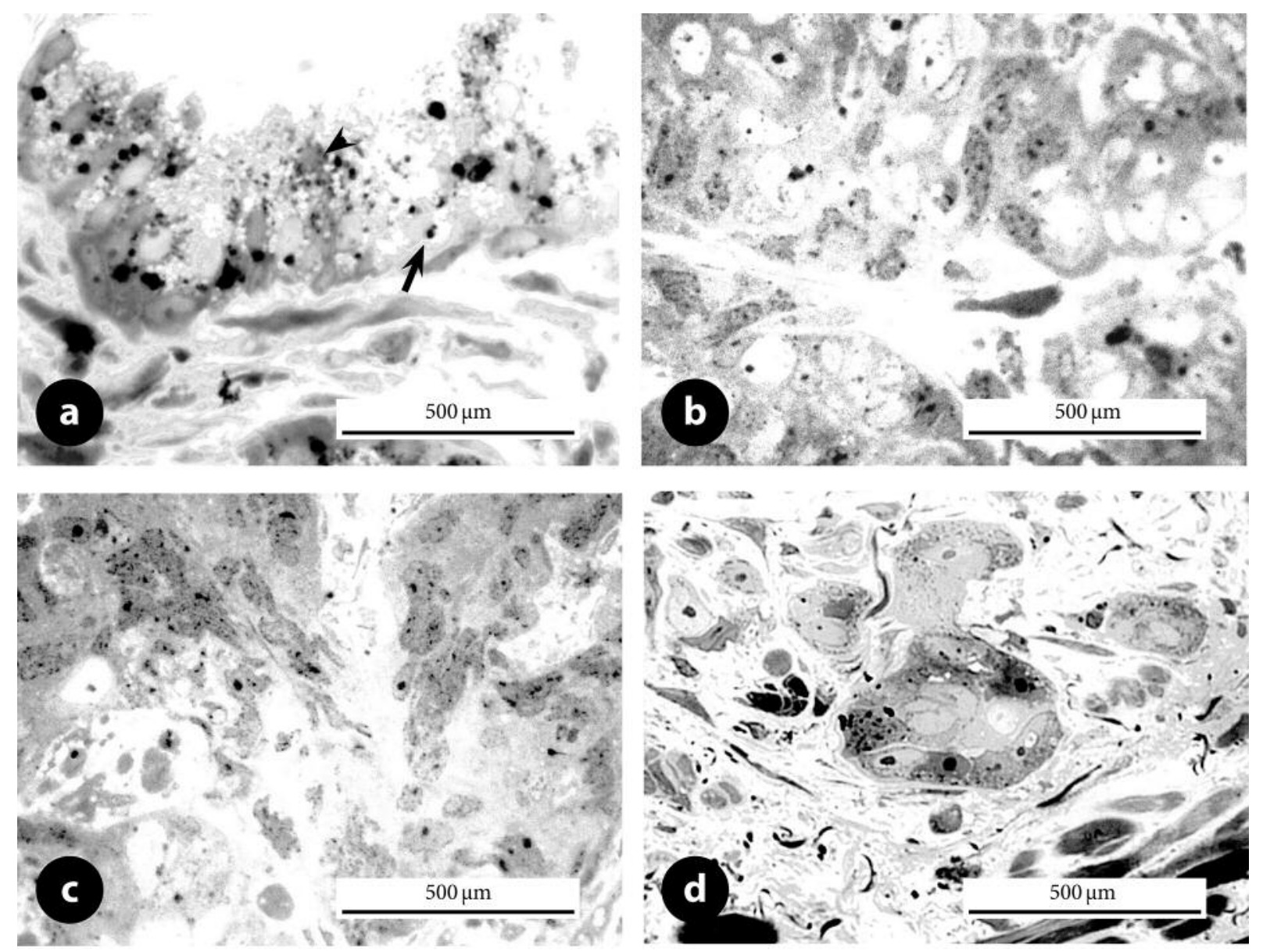

Figure 4. Stem cells in treated prostate cancer. a: Prostate cancer treated with diethylstilbestrol (DES) for 67 days showing localization of CD133 in dark and light stem cells by immunogold particles. Arrowhead illustrates localization of gold particles in a dark stem cell and that in a light stem cell is shown by an arrow. $b$, $c$ : Prostate cancer treated with DES for 67 days shows localization of CD133 in dark and light stem cells by immunogold particles. $d$ : Prostate cancer treated with DES for 37 days shows localization of CD133 in dark and light stem cells by immunogold particles. Invasive stem cell in prostatic stroma illustrates localization of gold particles.

light basal cells (Figure 4d). The presence of an invasive cell in the stroma localizing CD133, as shown by gold particles indicated that the cancer stem cell had migrated from the acinus to stroma.

\section{Discussion}

In 1977, we identified light and dark basal cells after methylene blue staining of sections of untreated and DEStreated PC (22). CD133 antibody was not available at the time. In a recent article, we reported that light cells had androgen receptors and dark cells had estrogen receptors (23). Our approach of Epon-embedding, methylene blue staining and localization of CD133 showed that prostate and PC have two types of stem cells, light and dark stem cells.
We did not study progesterone-dependent cells, but others have (14-17). CD133 does not distinguish between light and dark stem cells, but methylene blue staining does.

Basal cells are more undifferentiated cell than stem cells, as shown by transmission electron microscopy (22, 23, 29). The basal/stem cells found in the basal compartment differ in function from the secretory columnar/cuboidal cells in the luminal compartment. Regulations of these cells differ in prostate. For example, basal/stem cells do not degenerate in untreated and DEStreated human PC and in castrated mice (22-24). In contrast, columnar/cuboidal cells degenerate, slough and die in response to ADT or castration in mice. This indicates that basal/stem cells are not dependent on steroid hormones, but columnar/cuboidal cells are. This also indicates that stem cells in the basal compartment are 
independent of the luminal compartment. We determined that proliferation of stem cells produces a lineage of columnar/cuboidal cells. In contrast, Kasper stated that human PC is derived from the luminal cell lineage (4). Furthermore, stem cells are therefore closer in proximity to circulating mutagens, resulting in mutation in the genes of the stem cells, producing cancer stem cells. Cancerous mutation confers unlimited potential for proliferation in PC cells, but not in benign prostate.

The above observation has led us to propose that stem cells and their genes are organ-specific in adult prostate, breast and other solid organs. Stem cells and their genes acquire organ-specific (or unipotential) characteristics in contrast to pluripotent characteristics in the embryo. Embryonic stem cells and their genes are responsible for the development of specific organs during organogenesis. Once an organ has developed, the embryonic stem cells continue to function in the adult organ as organ-specific stem cells. This is supported by observation that stem cells proliferate and produce differentiated columnar/cuboidal cells, which when sloughed are replenished or replaced by stem cells when necessary (see above). Stem cells have the ability to proliferate and differentiate into columnar/cuboidal cells as well as slough, replenish and replace dead cells when necessary. In other words, once stem cells and their genes have completed organ-specific development during organogenesis, they continue to support function in the adult prostate. There is a continuity of embryonic stem cells and their genes in adult organs. There is no evidence that adult prostate produces a new set of stem cells $(2-5,8-10,12,13$, $30)$. We also postulate that embryonic stem cells persist in breast, uterus, cervix and other organs in adults. The above hypothesis needs to be further studied.

Androgen-dependent columnar/cuboidal cells are the lineage of light stem cells, whereas dark cells also have lineage of cuboidal cuboidal/columnar cells, they emerged after ADT treatment [see (23) for details]. The lineage of dark cells is under the influence of estrogen. This also indicates the failure of ADT treatment, as detailed in earlier studies $(22,23)$. Others have suggested the role of androgen and estrogen receptors for PC stem cells (14-17). Some have suggested that cancer stem cells are involved in the development of cancer castration-resistant PC and they should be targeted (31-34). We have suggested that ADT failure leads to loss of androgen-dependent cells. Prostatic cells thereby become estrogen-dependent since androgen has been essentially removed by ADT. This leads to the development of castration-resistant PC (23). Castrationresistant tumor is, therefore, under the control of estrogen and not androgen. We have recommended that castrationresistant $\mathrm{PC}$, should be treated with drugs for estrogen ablation (such tamoxifen, or aromatase inhibitors) and not by abiraterone acetate and enzalutamide [see (23)].

\section{Conclusion}

The basal compartment of the prostate is a privileged site for stem cells. Stem cells are not under the regulation of steroid hormones. There is a continuity of embryonic stem cells into the adult prostate. There is no evidence that adult prostate produces a new set of stem cells. Stem cells in adult prostate proliferate to produce a lineage of differentiated columnar/ cuboidal cells and replenish them when they are lost by sloughing, or cell death in the luminal compartment. Epon embedding and methylene blue staining showed two types of CD133-positive stem cells exist in prostate. In contrast, paraffin embedding showed only a single type of stem cell. The current stem cell therapies used for many types of cancer may simply have a placebo effect on patients, but an effective therapy could be developed for both prostate and breast cancer considering our findings.

\section{Conflicts of Interest}

The Authors have no conflict of interest to report regarding the publication of this article.

\section{Disclaimer}

The opinion expressed in this article is that of the Authors and not of the U.S. Government, Department of Veterans Affairs or the University of Minnesota.

\section{Acknowledgements}

This research was supported in part by the Research Service of the Minneapolis Veterans Affairs Medical Center by providing laboratory and other research facilities to AAS. We are grateful to Dr. Donald F. Gleason and Dr. Nancy A. Staley, former pathologists of the Minneapolis VA Medical Center, for grading the PC sections. We are also grateful to Dr. Clyde E. Blackard and his associates for biopsy and prostatectomy specimens and to Dr. Joel Slayton, former urologist at the Urologic Surgery at the VA Medical Center and the University of Minnesota, who consulted on the study. We also are very grateful to Drs. John Ohlfest and S. K. Swaminathan (University of Minnesota, Minneapolis, MN) for providing the CD133 antibody and Mr. Francis F. Pomroy, Jr. for immunogold localization of stem cells. We also thank Mr. Dennis J. Knapp of VA Medical Center for localization of CD133 in paraffin sections. Many thanks are due to Mr. Jonathan Erickson and James S. Hungaski of the VA Medical Center Media Service for making the final plates of microphotographs; the staff of the Departments of Surgical Pathology, Library, and the Research Service. Mr. Gary Saxrud and Mr. George De Beck of Nikon Instruments, Minneapolis, MN, USA for image analysis technical support.

\section{References}

1 Taylor RA, Cowin PA, Cunha GR, Pera M, Trounson AO, Pedersen J and Risbrigdger GP: Formation of human prostate tissue from embryonic stem cells. Nat Meth 3: 179-181, 2006. 
2 De Marzo AM, Nelson WG, Meeker AK and Coffey DS: Stem cell features of benign and malignant prostate epithelial cells. J Urol 160(6 Pt 2): 2381-2392, 1998.

3 Lang, SH, Frame FM and Collins AT: Prostate cancer stem cells. J Pathol 217: 299-306, 2009.

4 Kasper S: Exploring the origins of the normal prostate and prostate cancer stem cell. Stem Cell Rev 4: 193-201, 2008.

5 Collins AT and Maitland NJ: Prostate cancer stem cells. Eur J Cancer 42: 1213-1218, 2006.

6 Miki J, Furusato B, Li H, Gu Y, Takahashi H, Egawa S, Sesterhenn IA, McLeod DG, Shiv S and Rhim JS: Identification of putative stem cell markers, CD133 and CXCR4, in hTERTimmortalized primary nonmalignant and malignant tumorderived human prostate epithelial cell lines and prostate cancer specimens. Cancer Res 67: 3153-3161, 2007.

7 Collins AT, Habib FK, Maitland NJ and Neal DE: Identification and isolation of human prostate epithelial stem cells based on alpha-2 beta-1-integrin expression. J Cell Sci 114: 3865-3872, 2001.

8 Clarke MF, Dick JE, Dirks PB, Eaves CJ, Jamieson CHM, Jones DL, Visvader J, Weissman IL and Wahl GM: Cancer stem cells perspectives on current status and future directions: AACR workshop on cancer stem cells. Cancer Res 66: 9339-9344, 2006.

9 Richardson GD, Robson C N, Lang S, H., Neal DE, Maitland NJ and Collins AT: CD133, a novel marker for human prostatic epithelial stem cells. J Cell Sci 117: 3539-3545, 2004.

10 Jaworska D, Krol W and Szliszka E: Prostate cancer stem cells: Research advances. Int J Mol Sci 16(11): 27433-27449, 2015.

11 Smith CV, Bauer JJ, Connelly RR, Seay T, Kane C, Foley J, Thrasher JB, Kusuda L and Moul JW: Prostate cancer in men age 50 years or younger: A review of the Department of Defense Center for Prostate Disease Research multicenter prostate cancer data base. J Urol 164: 1964-1967, 2000.

12 Cabarcas SM, Mathews LA and Farrar WL: The cancer stem cell niche - There goes the neighborhood. Int J Cancer 129: 23152327, 2011.

13 Kelly K and Yin JJ: Prostate cancer and metastasis-initiating stem cells. Cell Res 18(5): 528-537, 2008.

14 Bashirelahi N, Yamanaka H, Young JD, Ito Y, Shida K and Harada M: Androgen, estrogen, and progesterone receptors in peripheral and central zone of human prostate with adenocarcinoma. Urol 21: 530-535, 1983.

15 Greene GL, Sobel NB, King WJ and Jensen EV: Immunohistochemical studies of estrogen receptors. J Steroid Biochem 20: 51-56, 1984.

16 Lau K-M, LaSpina M, Long $\mathrm{J}$ and Ho S-M: Expression of estrogen receptor (ER)-alpha and ER beta in normal and malignant prostatic epithelial cells: Regulation by methylation and involvement in growth regulation. Cancer Res 60: 31753182, 2002.

17 Hu W-Y, Shi G-B, Hu D-P, Nelles JR and Prins GS: Actions of estrogen and endocrine-disrupting chemicals on human prostate stem/progenitor cells and prostate cancer risk. Mol Cell Endocrinol 354: 63-73, 2012.

18 Sinha AA, Blackard CE, Doe RP and Seal US: The in vitro localization of $\mathrm{H} 3$ estradiol in human prostatic carcinoma: An electron microscopic autoradiographic study. Cancer 31: 682$688,1973$.

19 Henzller C, Li Y, Yang R, McBride T, Ho Y, Sprenger C, Liu G, Coleman I, Lakely B, Li R, Ma S, Landman SR, Kumar V, Hwang TH, Raj GV, Higano CS, Morrisey C, Nelson PS,
Plymate SR and Dehm S: Truncation and constitutive activation of androgen receptor by diverse genomic rearrangements in prostate cancer. Nat Commun 7: 1-44, 2016.

20 Ryan CJ and Tindal DJ: Androgen receptor rediscovered: The new biology and targeting the androgen receptor therapeutically. J Clinic Oncol 29: 3651-3658, 2011.

21 Li L-C, Chul R, Nakajima K, Oh BR, Au HC and Dahiya R: Frequent methylation of estrogen receptor in prostate cancer: Correlation with tumor progression. Cancer Res 60: 702-706, 2000.

22 Sinha AA, Blackard CE and Seal US: A critical analysis of tumor morphology and hormone treatments in the untreated and estrogen-treated responsive and refractory human prostatic carcinoma. Cancer 40(6): 2836-2850, 1977.

23 Sinha AA, Pomroy FE Jr. and Wilson MJ: Concurrent androgen and estrogen ablation and inhibition of steroid biosynthetic enzyme treatment for castration-resistant prostate cancer. Anticancer Res 36(8): 3847-3854, 2016.

24 Sinha AA and Bentley MD: The relationship of epithelial cell types in the ventral prostate glands of castrated mice treated with testosterone. Anat Rec 208: 533-544, 1984.

25 Gleason DF and VACURG (Veterans Affairs Co-operative Urologic Group): Histologic grading and clinical staging of prostatic carcinoma. In: Urologic Pathology: The Prostate. Tannenbaum M (ed.). Lea \& Febiger: Philadelphia, PA, pp. 171-213, 1977.

26 Ellis JW and Brawer MK: The role of tumor markers in the diagnosis and treatment of prostate cancer. In: Prostate Diseases. Lepor H and Lawson RK (eds.). W.B. Saunders Co: Philadelphia, pp. 276-292, 1993.

27 Swaminaathan SK, Olin MR, Forestor CL, Cruz KS, Panyam J and Ohlfest J: Identification of a novel monoclonal antibody recognizing CD133 J Immunnol Methods 36: 110-115, 2010.

28 Dougherty MM and King JS: A simple, rapid staining procedure for methacrylate embedded tissue sections using chronotrope $2 \mathrm{R}$ and methylene blue. Stain Tech 59: 149-153, 1984.

29 Sinha AA and Blackard CE: Ultrastructure of prostatic benign hyperplasia and carcinoma. Urology 2: 114-120, 1973.

30 Smith BA. Sokolov A, Uzunangelov V, Baertsch R, Newton Y, Graim K, Mathis C, Cheng D, Stuart JM and Witte ON: A basal stem cell signature identifies aggressive prostate cancer phenotypes. Proc Natl Acad Sci USA 112: E6542-E6552, 2015.

31 Yun E-J, Zhou J, Lin C-J, Hernandez E, Fazil L, Gleave M and Hsieh J-T: Targeting cancer stem cells in castration-resistant prostate cancer. Clin Cancer Res 22: 1-23, 2016.

32 Harris KS and Kerr BA: Prostate cancer stem cell markers drive progression, therapeutic resistance and bone metastasis. Stem Cell Int 2017: 1-9, 2017.

33 Sharaifi N: Minireview: Androgen metabolism in castrationresistant prostate cancer. Mol Endocrinol 27: 706-714, 2013.

34 Di Zazzo E, Galasso G, Giovannelli P, Di Donato M, Di Santi A, Cernera G, Rossi V, Abbondanza C, Moncharmont B, Sinisi AA, Castoria G and Migliaccio A: Prostate cancer stem cells: The role of androgen and estrogen receptors. Oncotarget $7(1)$ : 193-208, 2016. 